\title{
Metabolic syndrome and hepatocellular carcinoma risk
}

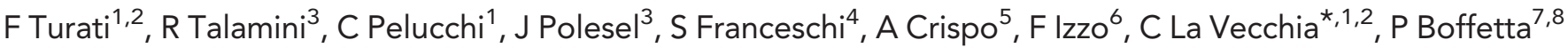 \\ and M Montella ${ }^{5}$ \\ ${ }^{1}$ Istituto di Ricerche Farmacologiche 'Mario Negri', via G. La Masa 19, 20156 Milan, Italy; ${ }^{2}$ Dipartimento di Scienze Cliniche e di \\ Comunità, Università degli Studi di Milano, via Vanzetti 5, 20133 Milan, Italy; ${ }^{3}$ SOC di Epidemiologia e Biostatistica, Centro di \\ Riferimento Oncologico, Via F. Gallini 2, 33081 Aviano (PN), Italy; ${ }^{4}$ International Agency for Research on Cancer, 150 Cours Albert \\ Thomas, 69372 Lyon CEDEX 08, France; ${ }^{5}$ Dipartimento di Epidemiologia, 'Fondazione G. Pascale', Istituto Nazionale Tumori, via \\ M. Semmola, 80131 Naples, Italy; ${ }^{6}$ Divisione di Chirurgia Istituto Nazionale dei Tumori Fondazione 'G. Pascale', via M. Semmola, \\ 80131 Naples, Italy; ${ }^{7}$ International Prevention Research Institute, Cours Lafayette 95, 69006 Lyon France and ${ }^{8}$ Institute for \\ Transitional Epidemiology and Tisch Cancer Institute, Mount Sinai School of Medicine, One Gustave L. Levy Place, Box No. 1057, \\ New York, NY 10029, USA
}

Background: Hepatocellular carcinoma (HCC) has been associated to diabetes and obesity, but a possible association with the metabolic syndrome (MetS) and its potential interaction with hepatitis is open to discussion.

Methods: We analysed data from an Italian case-control study, including $185 \mathrm{HCC}$ cases and 404 controls. Odds ratios (ORs) and 95\% confidence intervals ( $\mathrm{Cls}$ ) were computed from unconditional logistic regression models.

Results: Among the MetS components, diabetes and obesity (i.e, body mass index (BMI) $\geqslant 30 \mathrm{~kg} \mathrm{~m}^{-2}$ ) were positively associated to $\mathrm{HCC}$ risk, with ORs of $4.33(95 \% \mathrm{Cl}, 1.89-9.86)$ and $1.97(95 \% \mathrm{Cl}, 1.03-3.79)$, respectively. The ORs for the MetS were $4.06(95 \% \mathrm{Cl}$, 1.33-12.38) defining obesity as $\mathrm{BMI} \geqslant 25$, and $1.92(95 \% \mathrm{Cl}, 0.38-9.76)$ defining it as $\mathrm{BMI} \geqslant 30$. The risk increased with the number of MetS components, up to an almost four-fold excess risk among subjects with $\geqslant 2$ MetS factors. Among subjects without chronic infection with hepatitis $B$ and/or $C$, the OR for those with $\geqslant 2$ MetS components was over six-fold elevated. There was no consistent association in subjects with serological evidence of hepatitis B and/or C infection.

Conclusion: This study found that the risk of HCC increases with the number of MetS components in subjects not chronically infected with hepatitis viruses.

Worldwide, liver cancer is the third most common cause of cancer death among men and the sixth one among women (Llovet et al, 2003; London and McGlynn, 2006). Hepatocellular carcinoma (HCC) is the most frequent histologic type of primary liver cancer (Stuver and Trichopoulos, 2008), accounting for up to $85 \%$ of cases. The predominant role of chronic infection with hepatitis $\mathrm{B}$ virus (HBV) and hepatitis $\mathrm{C}$ virus (HCV) in the aetiology of HCC is well documented (Llovet et al, 2003; London and McGlynn, 2006; Mueller et al, 2006). Advanced age, male gender, heavy alcohol drinking, tobacco smoking and cirrhosis are other important recognised HCC risk factors (Llovet et al, 2003; London \& McGlynn, 2006; Mueller et al, 2006).

The metabolic syndrome (MetS) is a series of metabolically related conditions, consistently associated with an increased risk of cardiovascular diseases (Alberti et al, 2006, 2009). Since the late 90s, several definitions have been developed for MetS; these were based on glucose intolerance-hyperglycemia-diabetes, obesity, hypertension and dyslipidemia, but differed in the details and 
criteria (Alberti and Zimmet, 1998; Third Report of the NCEP Expert Panel, 2002; Alberti et al, 2005; Grundy et al, 2005). MetS components reflect overnutrition and sedentary lifestyle resulting in excess adiposity. A consensus statement by the major scientific associations in the field of metabolic disorders proposed common criteria for the clinical diagnosis of the MetS ('joint interim statement'), that is, the presence of at least three of the following conditions: elevated waist circumference (for abdominal obesity), elevated triglycerides, reduced high-density lipoprotein (HDL) cholesterol, elevated blood pressure, and elevated fasting glucose (Alberti et al, 2009). Several epidemiological studies reported positive associations between obesity and diabetes and the risk of primary liver cancer, whereas data on the association with other MetS components are scanty (Adami et al, 1996; Wideroff et al, 1997; Lagiou et al, 2000; El-Serag et al, 2004; Yuan et al, 2004; Lai et al, 2006; Larsson and Wolk, 2007; Polesel et al, 2009). A limited number of studies analysed the relationship between MetS and liver cancer, suggesting a positive association (Russo et al, 2008; Inoue et al, 2009; Borena et al, 2011; Welzel et al, 2011), but quantification and particularly the possible relation between MetS and $\mathrm{HBV} / \mathrm{HCV}$ remain open to discussion.

We provided further results on this issue using data from a multicentric case-control study conducted in Italy. In addition, we explored the association between MetS and HCC risk among subgroups of hepatitis-free and affected subjects.

\section{MATERIALS AND METHODS}

Between 1999 and 2002, a case-control study on HCC was carried out in the province of Pordenone (North-eastern Italy) and in the city of Naples (southern Italy) (Talamini et al, 2004; Franceschi et al, 2006; Montella et al, 2011b). Cases were subjects younger than 85 years with incident HCC, admitted to teaching and general hospitals in Pordenone and Naples. Out of the 261 HCC cases satisfying the inclusion criteria, 3 refused the participation, 29 did not supply blood samples, and 44 did not have anthropometric measures at cancer diagnosis. For the remaining 185 cases (median age: 66 years, range: $43-84$ years), both questionnaire information and blood samples were available. Most of the HCC cases (78.2\%) were histologically or cytologically confirmed; for the remaining cases, cancer diagnosis was based on ultrasound, tomography and elevated $\alpha$-fetoprotein levels.

Controls were patients younger than 85 years admitted to the same hospitals for a wide spectrum of acute, non-neoplastic conditions. Patients whose hospital admission was due to diseases related to alcohol and tobacco, liver diseases (e.g., hepatitis, cirrhosis, and oesophageal varices) or other chronic diseases, which may have substantially modified their lifestyle, were excluded from the comparison group. Overall, 467 controls were contacted and 462 accepted to participate. Blood samples were available from 431 controls, and 404 provided information on body size (median age: 65 years, range: $40-82$ years). Twenty-six per cent of controls were admitted for traumas, $25 \%$ for acute surgical conditions, $24 \%$ for nontraumatic orthopaedic diseases, $14 \%$ for eye diseases, and $10 \%$ for other illnesses.

Each case and control provided a $15-\mathrm{ml}$ blood sample the same day of the interview. Sera were screened for antibodies against HCV (anti-HCV) using a third-generation MEIA (AxSYM HCV version 3.0; Abbott Diagnostic Division, Wiesbaden, Germany) and for Hepatitis B surface antigen (HBsAg) using microparticle enzyme immunoassay (AxSYM HBsAg version 2.0; Abbott Diagnostic Division). All study participants signed an informed consent form, according to the recommendations of the Board of Ethics of the National Cancer Institute of Aviano.
Cases and controls were interviewed during their hospital stay using a structured questionnaire including information on sociodemographic characteristics, lifestyle habits (e.g., tobacco smoking and alcohol drinking), usual diet, personal medical history, and family history of cancer. Self-reported information on height and weight at different ages was collected, and body mass index (BMI) was computed according to Quetelet's index (weight/height ${ }^{2}$, $\mathrm{kg} \mathrm{m}^{-2}$ ). As information on waist circumference was not available, abdominal obesity was defined using BMI, according to two different thresholds, that is, $\geqslant 25$ and $\geqslant 30 \mathrm{~kg} \mathrm{~m}^{-2}$. History of medical conditions, including type- 2 diabetes, drug-treated hypertension, and drug-treated or clinical diagnosis of hypercholesterolaemia was self-reported, and included age at first diagnosis. Diseases whose onset was $<1$ year before hospital admission were not considered.

The indicator of MetS was defined according to the criteria agreed in the 2009 joint interim statement (Alberti et al, 2009), adapted to our data, as the presence of at least three components among the following: (1) abdominal obesity, (2) history of a clinical diagnosis or drug-treated hypercholesterolaemia (as a proxy indicator of increased low-density lipoprotein/reduced HDL cholesterol levels), (3) history of drug-treated hypertension (as an alternate indicator of elevated blood pressure), and (4) history of diabetes. We also considered various components of the MetS separately.

Data analysis. Odds ratios (ORs) of HCC, and the corresponding 95\% confidence intervals (CIs), for MetS, its components or various combination of components, were derived using unconditional multiple logistic regression models, including terms for centre, sex, age $(<55,55-64,65-74, \geqslant 75$ years $)$, education $(<7,7-11, \geqslant 12$ years), alcohol drinking status (never, ex, current), and maximum lifetime alcohol intake $(<21, \geqslant 21$ drinks per week), smoking habits (never, ex, current: $<15$ cigarettes per day, current: $\geqslant 15$ cigarettes per day), HBsAg and/or anti-HCV positivity, and non-alcohol energy intake.

\section{RESULTS}

Table 1 shows the distribution of 185 cases of HCC and 404 controls according to centre, age, sex, and other covariates. Controls were more often females and were younger than cases. Cases were more likely than controls to have a low level of education, to smoke cigarettes, and to report heavy alcohol drinking; 147 cases (79\%) and 44 controls (11\%) had serological evidence of chronic infection with HBV and/or HCV.

Table 2 reports the ORs of HCC according to separate and combined components of the MetS. The OR for diabetes was 4.33 (95\% CI, 1.89-9.86); no association emerged with treated hypertension and hypercholesterolaemia. The ORs were 1.25 (95\% CI, $0.72-2.18$ ) for BMI $\geqslant 25 \mathrm{~kg} \mathrm{~m}^{-2}$ and 1.97 (95\% CI, 1.03-3.79) for BMI $\geqslant 30 \mathrm{~kg} \mathrm{~m}^{-2}$. When obesity was defined as BMI $\geqslant 25 \mathrm{~kg} \mathrm{~m}^{-2}$, as compared with subjects without any MetS component, the OR was 0.90 (95\% CI, 0.47-1.74) for those with one MetS component, and 1.74 (95\% CI, 0.82-3.69) for those with $\geqslant 2$ components ( $P$ for trend $=0.149$ ). The OR for the indicator of MetS was 4.06 (95\% CI, 1.33-12.38). When obesity was defined as $\mathrm{BMI} \geqslant 30 \mathrm{~kg} \mathrm{~m}^{-2}$, the ORs were 1.18 (95\% CI, 0.64-2.15) and 3.46 (95\% CI, 1.54-7.73) for those with one and $\geqslant 2$ MetS components, respectively ( $P$ for trend $=0.009$ ). The OR for the presence of the MetS indicator was 1.92 (95\% CI, 0.38-9.76).

Table 3 reports results for diabetes and obesity (the only two MetS components associated to HCC risk in our data set), and number of MetS components according to serological evidence of chronic infection with HBV and/or HCV, and in a subset of subjects (11 cases and 216 controls) without markers of chronic 
Table 1. Distribution of 185 cases of hepatocellular carcinoma and 404 controls according to selected variables. Italy, 1999-2002

\begin{tabular}{|c|c|c|c|c|}
\hline & \multicolumn{2}{|c|}{ Cases } & \multicolumn{2}{|c|}{ Controls } \\
\hline & $\mathbf{N}$ & $\%$ & $\mathbf{N}$ & $\%$ \\
\hline \multicolumn{5}{|l|}{ Centre } \\
\hline Aviano/Pordenone & 61 & 33 & 224 & 55 \\
\hline Naples & 124 & 67 & 180 & 45 \\
\hline \multicolumn{5}{|l|}{ Sex } \\
\hline Males & 149 & 81 & 278 & 69 \\
\hline Females & 36 & 19 & 126 & 31 \\
\hline \multicolumn{5}{|l|}{ Age (years) } \\
\hline$<55$ & 18 & 10 & 83 & 20 \\
\hline $55-64$ & 56 & 30 & 115 & 29 \\
\hline $65-74$ & 84 & 45 & 144 & 36 \\
\hline$\geqslant 75$ & 27 & 15 & 62 & 15 \\
\hline
\end{tabular}

\section{Education (years)}

\begin{tabular}{|l|c|c|c|c|}
\hline$<7$ & 126 & 68 & 225 & 56 \\
$7-11$ & 45 & 24 & 93 & 23 \\
$\geqslant 12$ & 14 & 8 & 86 & 21 \\
\hline
\end{tabular}

\section{Smoking habits}

\begin{tabular}{|l|l|l|l|l|}
\hline Never & 50 & 27 & 134 & 33 \\
Former & 67 & 36 & 165 & 41 \\
Current, cigarettes & & & & \\
per day & 35 & 19 & 54 & 13 \\
$1-14$ & 33 & 18 & 51 & 13 \\
$\geqslant 15$ & &
\end{tabular}

\section{Drinking habits}

\begin{tabular}{|l|c|c|c|c|}
\hline Abstainer & 16 & 9 & 62 & 15 \\
Current & 75 & 40 & 302 & 75 \\
Former & 94 & 51 & 40 & 10 \\
\hline
\end{tabular}

Maximal lifetime alcohol intake ${ }^{a}$ (drinks per week)

\begin{tabular}{|c|c|c|c|c|}
$<21$ & 64 & 35 & 186 & 46 \\
$\geqslant 21$ & 105 & 57 & 156 & 39 \\
\hline
\end{tabular}

Non-alcohol energy intake (quartiles ${ }^{\text {b) }}$

\begin{tabular}{|l|l|l|l|l|}
\hline I & 28 & 15 & 101 & 25 \\
II & 39 & 21 & 101 & 25 \\
III & 51 & 28 & 101 & 25 \\
IV & 67 & 36 & 101 & 25 \\
\hline
\end{tabular}

Hepatitis viruses ${ }^{c}$

\begin{tabular}{|l|c|c|c|c|}
\hline No & 38 & 21 & 360 & 89 \\
Yes & 147 & 79 & 44 & 11 \\
\hline
\end{tabular}

${ }^{a}$ Current and former drinkers combined.

${ }^{b}$ Quartiles were based on the distribution of non-alcohol energy intake among controls only.

${ }^{\mathrm{c}}$ Hepatitis was defined as $\mathrm{HBsAg}$ and/or anti-HCV positivity.

infection with HBV and/or HCV and with a lifetime alcohol intake $<21$ drinks per week. Results are given for obesity defined as BMI $\geqslant 30 \mathrm{~kg} \mathrm{~m}^{-2}$. Diabetes showed an about three-fold increase in risk of HCC in subjects with and without chronic hepatitis, although the association was significant in the HBsAg - and anti-HCV group only; obesity and the number of MetS components were associated to HCC in hepatitis-free subjects only, in particular, in those with moderate alcohol consumption.

The combined effect of overweight (i.e., BMI $\geqslant 25 \mathrm{~kg} \mathrm{~m}^{-2}$ ) and diabetes on HCC risk is shown in Figure 1. Compared with the lowest risk category, that is normal-weight subjects without diabetes, the ORs were 1.13 (95\% CI, 0.63-2.06) for overweight subjects without diabetes, 4.38 (95\% CI, 0.84-22.88) for diabetics of normal weight, and 4.75 (95\% CI, 1.75-12.89) for those with both conditions.

\section{DISCUSSION}

In this Italian data set, the risk of HCC increased with the number of MetS components, up to an almost four-fold excess risk among subjects with $\geqslant 2$ MetS factors, and to over six-fold in subjects without markers of chronic infection with $\mathrm{HBV}$ and/or HCV. There was no consistent association in subjects $\mathrm{HBsAg}+$ or anti$\mathrm{HVC}+$. Metabolic syndrome is a general definition including several factors linked to overweight and hyperinsulinemia. Of these, only diabetes and overweight/obesity were associated to HCC risk in this study, although the relation with BMI was influenced by the threshold chosen. However, inference on hypercholesterolaemia was limited by the availability of information on treated subjects only, who were infrequent in Italy at the time of data collection, and data on hypertension were related to drug-treated hypertension only.

Our results are in broad agreement with previous data on the issue, which showed a positive association of MetS with liver cancer (Russo et al, 2008; Inoue et al, 2009; Borena et al, 2011; Welzel et al, 2011). When the single MetS components were analysed separately, overweight/obesity and high blood glucose revealed the strongest associations with liver cancer (Inoue et al, 2009; Borena et al, 2011).

Of specific interest, we found an association between the number of MetS components and HCC risk only among subjects without markers of chronic infection with HBV and/or HCV. In the Japan Public Health center-based prospective Study Cohort II, MetS increased the risk of HCC also among subjects with HCV infection (Inoue et al, 2009). In that study, among the single metabolic factors, only overweight was, however, positively associated to $\mathrm{HCC}$ risk in anti-HCV + subjects. A 14 years follow-up study in Taiwan recruiting 23820 subjects, for a total of 291 HCC cases, found that obesity (i.e., BMI $\geqslant 30 \mathrm{~kg} \mathrm{~m}^{-2}$ ) and central obesity (i.e., waist circumference $>90$ in men and $>80$ in women) were independently associated with a two-fold and a fourfold increased HCC risk among HCV-seropositive subjects, respectively (Chen et al, 2008). In the same study, diabetes was associated with a two- to three-fold increased HCC risk, regardless of the presence of chronic infection with hepatitis viruses. However, the risk was highest in $\mathrm{HBsAg}-$ and anti-HCV + subjects (Chen et al, 2008).

Diabetes and obesity have been previously related to HCC risk. This study considers the role of their combined effect in the MetS, and their interaction, as well as the modifying effect of HBV and/or HCV on the relation between MetS and liver cancer risk. Diabetes, in fact, has been associated with an about two-fold increased risk of HCC (La Vecchia et al, 1994; Adami et al, 1996; La Vecchia et al, 1997; Wideroff et al, 1997; Lagiou et al, 2000; ElSerag et al, 2004; Yuan et al, 2004; Lai et al, 2006; Polesel et al, 2009; La Vecchia, 2011; Bosetti et al, 2012), and precedes the development of both cirrhosis and HCC (Tanaka et al, 1997; Dellon and Shaheen, 2005; London and McGlynn, 2006). Insulin resistance has been related to the accumulation of liver fat and to excess cancer risk through the insulin-related growth factors (La Vecchia et al, 2011). 
Table 2. Distribution of 185 cases of hepatocellular carcinoma and 404 controls, OR and corresponding $95 \% \mathrm{Cl}^{\mathrm{a}}$, according to separate, combined components and indicators of MetS. Italy, 1999-2002

\begin{tabular}{|c|c|c|c|c|c|}
\hline & \multicolumn{4}{|c|}{ All subjects } & \multirow{2}{*}{ OR $(95 \% \mathrm{Cl})^{\mathrm{a}}$} \\
\hline & \multicolumn{2}{|c|}{ Cases } & \multicolumn{2}{|c|}{ Controls } & \\
\hline \multicolumn{6}{|l|}{ Separate components } \\
\hline \multicolumn{6}{|l|}{ Diabetes } \\
\hline \multicolumn{6}{|l|}{ Treated hypertension } \\
\hline $\begin{array}{l}\text { No } \\
\text { Yes }\end{array}$ & $\begin{array}{r}144 \\
41\end{array}$ & $\begin{array}{l}78 \\
22\end{array}$ & $\begin{array}{l}288 \\
116\end{array}$ & $\begin{array}{l}71 \\
29\end{array}$ & $\begin{array}{c}\text { Ref } \\
1.13(0.61-2.09)\end{array}$ \\
\hline \multicolumn{6}{|l|}{ Treated hypercholesterolaemia } \\
\hline $\begin{array}{l}\mathrm{BMI} \geqslant 25 \mathrm{~kg} \mathrm{~m}^{-2} \\
\mathrm{No} \\
\text { Yes }\end{array}$ & $\begin{array}{r}71 \\
114\end{array}$ & $\begin{array}{l}38 \\
62\end{array}$ & $\begin{array}{l}146 \\
258\end{array}$ & $\begin{array}{l}36 \\
64\end{array}$ & $\begin{array}{c}\text { Ref } \\
1.25(0.72-2.18)\end{array}$ \\
\hline $\begin{array}{l}\mathrm{BMl} \geqslant 30 \mathrm{~kg} \mathrm{~m}^{-2} \\
\mathrm{No} \\
\text { Yes }\end{array}$ & $\begin{array}{r}147 \\
38\end{array}$ & $\begin{array}{l}80 \\
20\end{array}$ & $\begin{array}{r}323 \\
81\end{array}$ & $\begin{array}{l}80 \\
20\end{array}$ & $\begin{array}{c}\text { Ref } \\
1.97(1.03-3.79)\end{array}$ \\
\hline \multicolumn{6}{|l|}{ Combined components } \\
\hline \multicolumn{6}{|l|}{ Number of MetS components } \\
\hline $\begin{array}{l}\text { (a) Obesity: } \mathrm{BMI} \geqslant 25 \mathrm{~kg} \mathrm{~m}^{-2} \\
\text { None } \\
1 \\
\geqslant 2 \\
P \text { for trend }=0.149 \\
\text { Increment of } 1 \text { MetS component }\end{array}$ & $\begin{array}{l}53 \\
80 \\
52\end{array}$ & $\begin{array}{l}29 \\
43 \\
28\end{array}$ & $\begin{array}{l}105 \\
190 \\
109\end{array}$ & $\begin{array}{l}26 \\
47 \\
27\end{array}$ & $\begin{array}{c}\text { Ref } \\
0.90(0.47-1.74) \\
1.74(0.82-3.69) \\
1.39(0.99-1.95)\end{array}$ \\
\hline \multicolumn{6}{|l|}{ Indicator of $M e t S^{b}$} \\
\hline $\begin{array}{l}\text { (a) Obesity: BMI } \geqslant 25 \mathrm{~kg} \mathrm{~m}^{-2} \\
\text { No } \\
\text { Yes }\end{array}$ & $\begin{array}{r}175 \\
10 \\
\end{array}$ & $\begin{array}{r}95 \\
5\end{array}$ & $\begin{array}{r}388 \\
16\end{array}$ & $\begin{array}{r}96 \\
4\end{array}$ & $\begin{array}{c}\text { Ref } \\
4.06(1.33-12.38)\end{array}$ \\
\hline $\begin{array}{l}\text { (b) Obesity: BMI } \geqslant 30 \mathrm{~kg} \mathrm{~m}^{-2} \\
\text { No } \\
\text { Yes }\end{array}$ & $\begin{array}{r}181 \\
4\end{array}$ & $\begin{array}{r}98 \\
2\end{array}$ & $\begin{array}{r}394 \\
10\end{array}$ & $\begin{array}{r}98 \\
2\end{array}$ & $\begin{array}{c}\text { Ref } \\
1.92(0.38-9.76)\end{array}$ \\
\hline $\begin{array}{l}\text { Abbreviations: } \mathrm{BMI}=\text { body mass index; } \mathrm{Cl}=\mathrm{c} \\
{ }^{\mathrm{a}} \text { Estimated from unconditional logistic regres } \\
\text { positivity, and non-alcohol energy intake. } \\
\text { b At least three of the separate components. }\end{array}$ & $\begin{array}{l}\text { rval; } N \\
\text { justed }\end{array}$ & $\begin{array}{l}\text { rome } \\
\text { educ }\end{array}$ & axir & ntake, & ts, HBsAg and/or anti-HC \\
\hline
\end{tabular}

With reference to obesity, a meta-analysis, including $>6000$ cases from 10 cohort studies, showed an $89 \%$ excess HCC risk among obese (i.e, BMI, $\geqslant 30 \mathrm{~kg} \mathrm{~m}^{-2}$ ) compared with subjects of normal weight; the pooled relative risk associated to overweight (BMI ranging from 25 to $30 \mathrm{~kg} \mathrm{~m}^{-2}$ ) was 1.17 (95\% CI, 1.02-1.34).

The excess risk of liver cancer associated with overweight/ obesity and diabetes has been related to the development of nonalcoholic fatty liver disease (NAFLD) (Sanyal et al, 2010). NAFLD is characterised by excess fat accumulation in the liver, and ranges from isolated hepatic steatosis to non-alcoholic steatohepatitis (NASH), the more aggressive form of fatty liver disease, which can progress to cirrhosis and HCC (Neuschwander-Tetri and Caldwell, 2003; Larsson and Wolk, 2007; Siegel and Zhu, 2009; Montella et al, 2011a). However, NAFLD/NASH increases HCC risk even in the absence of cirrhosis (Ertle et al, 2011). Adipose tissue secretes a variety of bioactive hormones, collectively referred to as adipokines, which produce vascular endothelial growth factor, which may contribute to tumour progression (Rega et al, 2007). Excess 
Table 3. Distribution of 185 hepatocellular carcinoma cases and 404 controls, $\mathrm{OR}^{\mathrm{a}}$ and corresponding $95 \% \mathrm{Cl}$, according to diabetes and obesity, and number of MetS components, by serological evidence of chronic infection with hepatitis B and/or hepatitis C viruses. Italy, 1999-2002

\begin{tabular}{|c|c|c|c|c|c|c|}
\hline & \multicolumn{2}{|c|}{$\begin{array}{l}\mathrm{HBsAg}-\text { and } \\
\text { anti-HCV - }\end{array}$} & \multicolumn{2}{|c|}{$\begin{array}{l}\mathrm{HBsAg}-\text { and anti-HCV }- \text { and lifetime } \\
\text { alcohol intake }<21 \text { drinks per week }\end{array}$} & \multicolumn{2}{|c|}{$\begin{array}{l}\mathrm{HBsAg}+\text { or } \\
\text { anti-HCV }+\end{array}$} \\
\hline & Ca:Co & OR $\left(95 \% \mathrm{Cl}^{\mathrm{a}}\right.$ & $\mathrm{Ca}$ Co & OR $(95 \% \mathrm{Cl})^{\mathrm{a}}$ & Ca:Co & OR $(95 \% \mathrm{Cl})^{\mathrm{a}}$ \\
\hline \multicolumn{7}{|l|}{ Diabetes } \\
\hline No & $29: 337$ & Ref & $8: 203$ & Ref & $119: 41$ & Ref \\
\hline Yes & $9: 23$ & $3.65(1.37-9.75)$ & $3: 13$ & $9.14(1.39-60.29)$ & $28: 3$ & $2.57(0.61-10.64)$ \\
\hline \multicolumn{7}{|l|}{ Obesity $^{b}$} \\
\hline No & $22: 288$ & Ref & $7: 170$ & Ref & $125: 35$ & Ref \\
\hline Yes & $16: 72$ & $3.32(1.51-7.32)$ & $4: 46$ & $2.69(0.61-11.90)$ & $22: 9$ & $0.69(0.21-2.27)$ \\
\hline \multicolumn{7}{|c|}{ Number of MetS components } \\
\hline 0 & $12: 197$ & Ref & $2: 112$ & Ref & $85: 22$ & Ref \\
\hline 1 & $12: 116$ & $1.76(0.70-4.45)$ & $5: 74$ & $7.40(0.90-61.10)$ & $50: 17$ & $0.90(0.35-2.31)$ \\
\hline$\geqslant 2$ & $14: 47$ & $6.45(2.35-17.75)$ & $4: 30$ & $20.21(1.96-208.49)$ & $12: 5$ & $0.69(0.15-2.99)$ \\
\hline$P$ for trend & $<0.001$ & & 0.009 & & & 0.612 \\
\hline $\begin{array}{l}\text { Increment of } 1 \mathrm{MetS} \\
\text { component }\end{array}$ & $2.16(1.38-3.39)$ & & $3.41(1.31-8.89)$ & & $0.84(0.46-1.52)$ & \\
\hline \multicolumn{7}{|c|}{$\begin{array}{l}\text { Abbreviations: } \mathrm{Ca}=\text { cases; } \mathrm{Cl}=\text { confidence interval; } \mathrm{Co}=\text { controls; } \mathrm{HCV}=\text { hepatitis } \mathrm{C} \text { virus; } \mathrm{HBs} \mathrm{Ag}=\text { hepatitis } \mathrm{B} \text { surface antigen; Met } \mathrm{S}=\text { metabolic syndrome; } \mathrm{OR}=\text { odds ratio. } \\
{ }^{2} \text { Estimated from unconditional logistic regression model adjusted for centre, sex, age, education, drinking status (when appropriate), maximum lifetime alcohol intake (when appropriate), } \\
\text { smoking habits, and non-alcohol energy intake. } \\
{ }^{b} \text { Obesity was defined as body mass index (BMI) } \geqslant 30 \mathrm{~kg} \mathrm{~m}^{-2} \text {. }\end{array}$} \\
\hline
\end{tabular}

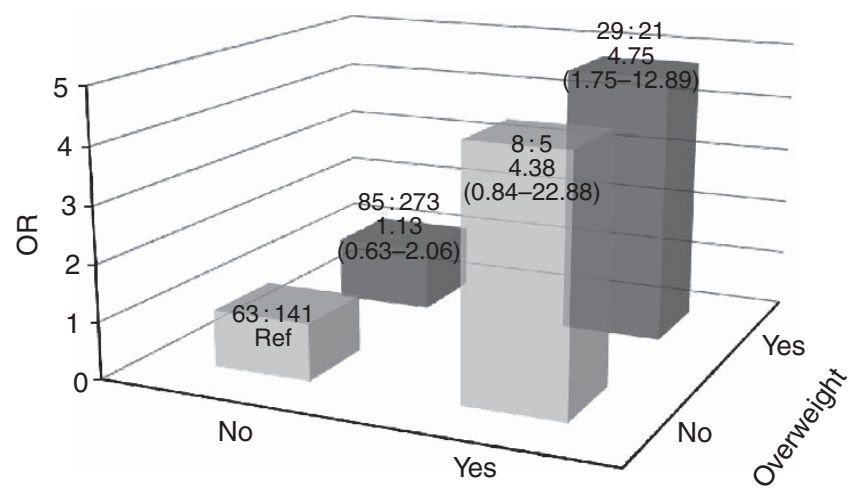

Diabetes

Figure 1. Distribution of 185 hepatocellular carcinoma cases and 404 controls, odds ratios (OR) and $95 \%$ confidence intervals $(\mathrm{Cls})$ according to the combination of diabetes and overweight. Italy, 1999-2002. ORs were estimated from unconditional logistic regression model adjusted for centre, sex, age, education, drinking status, maximum lifetime alcohol intake, smoking habits, HBsAg and/or anti-HCV positivity, and non-alcohol energy intake. Overweight was defined as BMI $\geqslant 25 \mathrm{~kg} \mathrm{~m}^{-2}$.

intracellular fatty acids, adenosine triphosphate depletion, oxidant stress, and mitochondrial dysfunction may cause hepatocellular injuries in the steatotic liver (Neuschwander-Tetri and Caldwell, 2003).

To limit possible sources of bias, we included in the control group subjects admitted for a wide spectrum of acute, nonneoplastic conditions, unrelated to the major risk factors for HCC. The practically complete participation rate and the comparable catchment areas of cases and controls contributed to reduce any potential selection bias. Cases may recall history of disease more frequently than controls. However, the hospital setting should have improved the comparability of information, as cases and controls are interviewed under similar conditions (Breslow and Day, 1980).
Among limitations, information on MetS components was based on self-reported data from a questionnaire, which collected history of diabetes, treated hypertension, and treated hyperlipidaemia, rather than direct measurements of fasting plasma glucose, blood pressure, triglycerides and HDL cholesterol. Underestimation of the prevalence of MetS may therefore have occurred. However, data on diabetes collected on our questionnaire were satisfactorily reliable, with a $\mathrm{k}$ statistic of 0.85 from almost 300 subjects interviewed twice (Bosetti et al, 2001). Moreover, a recent cohort study from Spain showed that self-declared data on the criteria of MetS and on MetS itself are sufficiently accurate for epidemiological inference (Barrio-Lopez et al, 2011). Validation studies of hypertension confirmed with a medical examination found a reasonable accuracy of self-reported information; a somewhat lower validity was usually found for self-reported hypercholesterolaemia (Colditz et al, 1986; Giles et al, 1995; Vargas et al, 1997; Martin et al, 2000). Weight also was selfreported and possibly underestimated, particularly in overweight and obese subjects (Stark et al, 1981; Stewart, 1982; Millar, 1986). However, such information bias is likely to be similar for cases and controls, and, consequently, should have led to an attenuation of the real association (Breslow and Day, 1980). In addition, information on presence of fatty liver/NAFLD/NASH was not available in our study.

Another possible limitation is the use of BMI as a proxy of waist circumference in defining people with central obesity. However, the World Health Organization, in its formulation of MetS diagnostic criteria, considered BMI as a valid proxy of waist-tohip ratio (Alberti et al, 2006). In our analyses, abdominal obesity was defined as either BMI $\geqslant 25$ or BMI $\geqslant 30 \mathrm{~kg} \mathrm{~m}^{-2}$, and the excess risk associated to the MetS persisted even when the lower threshold was considered. We used one of the possible MetS definition proposed in the literature (Alberti et al, 2009). When the presence of MetS was defined according to the International Diabetes Federation criteria (Third Report of the NCEP Expert Panel, 2002) (adapted to our data) as the presence of central obesity plus at least two other components, the OR for the 
indicator of MetS did not substantially change $(\mathrm{OR}=2.12,95 \% \mathrm{CI}$, $0.40-11.26$, with obesity defined as BMI $\geqslant 30 \mathrm{~kg} \mathrm{~m}^{-2} ; \mathrm{OR}=4.36$, $95 \%$ CI, 1.40-13.56, with obesity defined as BMI $\geqslant 25 \mathrm{~kg} \mathrm{~m}^{-2}$ ).

The different prevalence of chronic hepatitis infection with $\mathrm{HBV} / \mathrm{HCV}$ between HCC cases and controls, and the relatively low prevalence of obesity (i.e., BMI $\geqslant 30 \mathrm{~kg} \mathrm{~m}^{-2}$ ) and other MetS components in our study sample, limited our results on these associations, particularly in subgroup analyses. In light of these considerations, caution in interpreting these results is needed.

Concerning confounding, the associations persisted after adjustment for the main recognised HCC risk factors, including chronic infection with $\mathrm{HBV} / \mathrm{HCV}$, tobacco smoking, and alcohol drinking.

\section{ACKNOWLEDGEMENTS}

This work was conducted with the contribution of the Italian Association for Cancer Research (AIRC) (grant number: 10068), the Flight Attendants Medical Research Institute Center of Excellence (Award 052460_CoE), and the Italian League Against Cancer (LILT) (project number:11/2008). We thank Mrs I Garimoldi for her editorial assistance.

\section{REFERENCES}

Adami HO, Chow WH, Nyren O, Berne C, Linet MS, Ekbom A, Wolk A, McLaughlin JK, Fraumeni Jr JF (1996) Excess risk of primary liver cancer in patients with diabetes mellitus. J Natl Cancer Inst 88: 1472-1477.

Alberti KG, Eckel RH, Grundy SM, Zimmet PZ, Cleeman JI, Donato KA, Fruchart JC, James WP, Loria CM, Smith Jr SC (2009) Harmonizing the metabolic syndrome: a joint interim statement of the International Diabetes Federation Task Force on Epidemiology and Prevention; National Heart, Lung, and Blood Institute; American Heart Association; World Heart Federation; International Atherosclerosis Society; and International Association for the Study of Obesity. Circulation 120: $1640-1645$.

Alberti KG, Zimmet P, Shaw J (2005) The metabolic syndrome-a new worldwide definition. Lancet 366: 1059-1062.

Alberti KG, Zimmet P, Shaw J (2006) Metabolic syndrome-a new world-wide definition. A Consensus Statement from the International Diabetes Federation. Diabet Med 23: 469-480.

Alberti KG, Zimmet PZ (1998) Definition, diagnosis and classification of diabetes mellitus and its complications. Part 1: diagnosis and classification of diabetes mellitus provisional report of a WHO consultation. Diabet Med 15: 539-553.

Barrio-Lopez MT, Bes-Rastrollo M, Beunza JJ, Fernandez-Montero A, GarciaLopez M, Martinez-Gonzalez MA (2011) Validation of metabolic syndrome using medical records in the SUN cohort. BMC Public Health 11: 867 .

Borena W, Strohmaier S, Lukanova A, Bjorge T, Lindkvist B, Hallmans G, Edlinger M, Stocks T, Nagel G, Manjer J, Engeland A, Selmer R, Haggstrom C, Tretli S, Concin H, Jonsson H, Stattin P, Ulmer H (2011) Metabolic risk factors and primary liver cancer in a prospective study of 578700 adults. Int J Cancer 131(1): 193-200.

Bosetti C, Rosato V, Polesel J, Levi F, Talamini R, Montella M, Negri E, Tavani A, Zucchetto A, Franceschi S, Corrao G, La Vecchia C (2012) Diabetes mellitus and cancer risk in a network of case-control studies. Nutr Cancer 64: 643-651.

Bosetti C, Tavani A, Negri E, Trichopoulos D, La Vecchia C (2001) Reliability of data on medical conditions, menstrual and reproductive history provided by hospital controls. J Clin Epidemiol 54: 902-906.

Breslow NE, Day NE (1980) Statistical methods in cancer research. Vol. I. The analysis of case-control studies. IARC: Lyon, France.

Chen CL, Yang HI, Yang WS, Liu CJ, Chen PJ, You SL, Wang LY, Sun CA, Lu SN, Chen DS, Chen CJ (2008) Metabolic factors and risk of hepatocellular carcinoma by chronic hepatitis B/C infection: a follow-up study in Taiwan. Gastroenterology 135: 111-121.

Colditz GA, Martin P, Stampfer MJ, Willett WC, Sampson L, Rosner B, Hennekens CH, Speizer FE (1986) Validation of questionnaire information on risk factors and disease outcomes in a prospective cohort study of women. Am J Epidemiol 123: 894-900.

Dellon ES, Shaheen NJ (2005) Diabetes and hepatocellular carcinoma: associations, biologic plausibility, and clinical implications. Gastroenterology 129: 1132-1134.

El-Serag HB, Tran T, Everhart JE (2004) Diabetes increases the risk of chronic liver disease and hepatocellular carcinoma. Gastroenterology 126: 460-468.

Ertle J, Dechene A, Sowa JP, Penndorf V, Herzer K, Kaiser G, Schlaak JF, Gerken G, Syn WK, Canbay A (2011) Non-alcoholic fatty liver disease progresses to hepatocellular carcinoma in the absence of apparent cirrhosis. Int J Cancer 128: 2436-2443.

Franceschi S, Montella M, Polesel J, La Vecchia C, Crispo A, Dal Maso L, Casarin P, Izzo F, Tommasi LG, Chemin I, Trepo C, Crovatto M, Talamini R (2006) Hepatitis viruses, alcohol, and tobacco in the etiology of hepatocellular carcinoma in Italy. Cancer Epidemiol Biomarkers Prev 15: 683-689.

Giles WH, Croft JB, Keenan NL, Lane MJ, Wheeler FC (1995) The validity of self-reported hypertension and correlates of hypertension awareness among blacks and whites within the stroke belt. Am J Prev Med 11: 163-169.

Grundy SM, Cleeman JI, Daniels SR, Donato KA, Eckel RH, Franklin BA, Gordon DJ, Krauss RM, Savage PJ, Smith Jr SC, Spertus JA, Costa F (2005) Diagnosis and management of the metabolic syndrome: an American Heart Association/National Heart, Lung, and Blood Institute Scientific Statement. Circulation 112: 2735-2752.

Inoue M, Kurahashi N, Iwasaki M, Tanaka Y, Mizokami M, Noda M, Tsugane S (2009) Metabolic factors and subsequent risk of hepatocellular carcinoma by hepatitis virus infection status: a large-scale populationbased cohort study of Japanese men and women (JPHC Study Cohort II). Cancer Causes Control 20: 741-750.

La Vecchia C (2011) Diabetes mellitus, medications for type 2 diabetes mellitus, and cancer risk. Metabolism 60: 1357-1358.

La Vecchia C, Giordano SH, Hortobagyi GN, Chabner B (2011) Overweight, obesity, diabetes, and risk of breast cancer: interlocking pieces of the puzzle. Oncologist 16: 726-729.

La Vecchia C, Negri E, Decarli A, Franceschi S (1997) Diabetes mellitus and the risk of primary liver cancer. Int J Cancer 73: 204-207.

La Vecchia C, Negri E, Franceschi S, D’Avanzo B, Boyle P (1994) A casecontrol study of diabetes mellitus and cancer risk. Br J Cancer 70: 950-953.

Lagiou P, Kuper H, Stuver SO, Tzonou A, Trichopoulos D, Adami HO (2000) Role of diabetes mellitus in the etiology of hepatocellular carcinoma. J Natl Cancer Inst 92: 1096-1099.

Lai MS, Hsieh MS, Chiu YH, Chen TH (2006) Type 2 diabetes and hepatocellular carcinoma: a cohort study in high prevalence area of hepatitis virus infection. Hepatology 43: 1295-1302.

Larsson SC, Wolk A (2007) Overweight, obesity and risk of liver cancer: a meta-analysis of cohort studies. Br J Cancer 97: 1005-1008.

Llovet JM, Burroughs A, Bruix J (2003) Hepatocellular carcinoma. Lancet 362: 1907-1917.

London WT, McGlynn KA (2006) Liver cancer. In Cancer Epidemiology and Prevention, Schottenfeld D, Fraumeni Jr JF (eds)3rd ednpp 763-786. Oxford University Press: New York.

Martin LM, Leff M, Calonge N, Garrett C, Nelson DE (2000) Validation of self-reported chronic conditions and health services in a managed care population. Am J Prev Med 18: 215-218.

Millar WJ (1986) Distribution of body weight and height: comparison of estimates based on self-reported and observed measures. J Epidemiol Community Health 40: 319-323.

Montella M, Crispo A, Giudice A (2011a) HCC, diet and metabolic factors: Diet and HCC. Hepat Mon 11: 159-162.

Montella M, Polesel J, Talamini R, Crispo A, Giudice A, Izzo F, La Vecchia C (2011b) Metabolic syndrome is also a risk factor for primary liver cancer in patients younger than 65 years of age? Hepatology 54: 2277-2278.

Mueller NE, Birmann BM, Parsonnet J, Schiffman MH, Stuver S (2006) Infectious agents. In Cancer Epidemiology and Prevention, Schottenfeld D, Fraumeni JJ (eds) 3rd edn pp 507-548. Oxford Universiy Press: New York.

Neuschwander-Tetri BA, Caldwell SH (2003) Nonalcoholic steatohepatitis: summary of an AASLD Single Topic Conference. Hepatology 37: 1202-1219.

Polesel J, Zucchetto A, Montella M, Dal Maso L, Crispo A, La Vecchia C, Serraino D, Franceschi S, Talamini R (2009) The impact of obesity and diabetes mellitus on the risk of hepatocellular carcinoma. Ann Oncol 20: 353-357. 
Rega G, Kaun C, Demyanets S, Pfaffenberger S, Rychli K, Hohensinner PJ, Kastl SP, Speidl WS, Weiss TW, Breuss JM, Furnkranz A, Uhrin P, Zaujec J, Zilberfarb V, Frey M, Roehle R, Maurer G, Huber K, Wojta J (2007) Vascular endothelial growth factor is induced by the inflammatory cytokines interleukin- 6 and oncostatin $\mathrm{m}$ in human adipose tissue in vitro and in murine adipose tissue in vivo. Arterioscler Thromb Vasc Biol 27: 1587-1595.

Russo A, Autelitano M, Bisanti L (2008) Metabolic syndrome and cancer risk. Eur J Cancer 44: 293-297.

Sanyal AJ, Yoon SK, Lencioni R (2010) The etiology of hepatocellular carcinoma and consequences for treatment. Oncologist 15(Suppl 4): 14-22.

Siegel AB, Zhu AX (2009) Metabolic syndrome and hepatocellular carcinoma: two growing epidemics with a potential link. Cancer 115: 5651-5661.

Stark O, Atkins E, Wolff OH, Douglas JW (1981) Longitudinal study of obesity in the National Survey of Health and Development. Br Med J 283: 13-17.

Stewart AL (1982) The reliability and validity of self-reported weight and height. J Chronic Dis 35: 295-309.

Stuver S, Trichopoulos D (2008) Cancer of the liver and biliary tract. In Cancer Epidemiology, Adami H-O, Hunter D, Trichpoulos D (eds) 2nd edn pp 308-332. Oxford Universiy Press: New York.

Talamini R, Montella M, Crovatto M, Dal Maso L, Crispo A, Negri E, Spina M, Pinto A, Carbone A, Franceschi S (2004) Non-Hodgkin's lymphoma and hepatitis $\mathrm{C}$ virus: a case-control study from northern and southern Italy. Int J Cancer 110: 380-385.
Tanaka S, Mohr L, Schmidt EV, Sugimachi K, Wands JR (1997) Biological effects of human insulin receptor substrate-1 overexpression in hepatocytes. Hepatology 26: 598-604.

Third Report of the National Cholesterol Education Program (NCEP) Expert Panel on Detection, Evaluation, and Treatment of High Blood Cholesterol in Adults (Adult Treatment Panel III) final report (2002) Circulation 106: 3143-3421.

Vargas CM, Burt VL, Gillum RF, Pamuk ER (1997) Validity of self-reported hypertension in the National Health and Nutrition Examination Survey III, 1988-1991. Prev Med 26: 678-685.

Welzel TM, Graubard BI, Zeuzem S, El-Serag HB, Davila JA, McGlynn KA (2011) Metabolic syndrome increases the risk of primary liver cancer in the United States: a study in the SEER-Medicare database. Hepatology 54: $463-471$.

Wideroff L, Gridley G, Mellemkjaer L, Chow WH, Linet M, Keehn S, Borch-Johnsen K, Olsen JH (1997) Cancer incidence in a populationbased cohort of patients hospitalized with diabetes mellitus in Denmark. J Natl Cancer Inst 89: 1360-1365.

Yuan JM, Govindarajan S, Arakawa K, Yu MC (2004) Synergism of alcohol, diabetes, and viral hepatitis on the risk of hepatocellular carcinoma in blacks and whites in the U.S. Cancer 101: 1009-1017.

This work is published under the standard license to publish agreement. After 12 months the work will become freely available and the license terms will switch to a Creative Commons AttributionNonCommercial-Share Alike 3.0 Unported License. 